\title{
Małgorzata GASZYŃSKA-MAGIERA
}

Uniwersytet Warszawski

m.gaszynska-ma@uw.edu.pl

\section{PRZEKŁAD LITERACKI JAKO POSTPAMIĘĆ W PODRÓŻY}

\section{O WARUNKACH RECEPCJI POLSKICH POWIEŚCI O TEMATYCE POSTPAMIĘCIOWEJ W HISZPANII}

ABSTRACT Literary Translation as Travelling Memory. On the Circumstances of the Reception of Polish Postmemorial Novels in Spain

The phenomenon of the translation of postmemorial novels could be interpreted as a case of a so called travelling memory. The notion of postmemory connotes a temporal shift, while the process of translation implies a spacial one. In order to study the reception of such literary works in a foreign context, it is necessary not only to take into account such aspects as the knowledge of the receiving public about their historical background and the source literary system but also the existence - or lack - of parallel literary forms of expressing memory in the target culture. In the article, conditions of the reception in Spain of three Polish postmemorial novels, Weiser Dawidek by Paweł Huelle, Hanemann by Stefan Chwin and Tworki by Marek Bieńczyk, are discussed on.

Keywords: postmemory, literary translation, reception, contemporary Polish novel

Słowa kluczowe: postpamięć, przekład literacki, recepcja, polska powieść współczesna 


\section{POSTPAMIĘĆ JAKO FENOMEN PSYCHOLOGICZNY}

Marianne Hirsch ${ }^{1}$ zdefiniowała postpamięć jako pamięć odziedziczoną czy wręcz fałszywą, bo dotyczącą wydarzeń, których nie doświadczyło się osobiście. To pamięć traumy zbiorowej ${ }^{2}$ ujawniająca się w drugim lub kolejnym pokoleniu. Termin ten opisuje pokoleniowe doświadczenie potomków Ocalonych, którzy dorastali w świecie naznaczonym tragedią poprzedniej generacji, generacji rodziców lub dziadków, tragedii, która miała miejsce przed ich narodzeniem. Ta cudza trauma przenika jednak ich życie, ich codzienność, nie można przed nią uciec. Przedstawiciele drugiego pokolenia żyją w cieniu potwornych wydarzeń, niemożliwych ani do zrozumienia, ani do zracjonalizowania. W konsekwencji nie są oni w stanie stworzyć własnej, odrębnej narracji, ponieważ znajdują się pod nieustannym wpływem wydarzeń, które nie były ich udziałem. To przez nie są kształtowani, a ich własne doświadczenia i historia ulegają w związku z tym deformacji i przewartościowaniu ${ }^{3}$.

Prace Hirsch zainspirowały do zajęcia się tą problematyką badaczy zajmujących się różnymi dziedzinami wiedzy. Jej tezy wzbudzały niekiedy także nieufność i krytykę. Jedną z kwestii, która powodowała największe wątpliwości, była dziedziczność pamięci. Stawiano więc pytania o to, czy pamięć rzeczywiście można przejąć po najbliższych, cudze wspomnienia traktować jak własne, oddzielić to, co rzeczywiście odziedziczone, od wiedzy nabytej choćby w procesie formalnej edukacji. Spór dotyczący istnienia takiego zjawiska jak postpamięć, który toczył się głównie w środowisku kulturoznawców i socjologów, ma już długą historię̧, nie jest to jednak miejsce na dokładne omawianie różnych stanowisk badawczych. Chciałabym natomiast odwołać się do badań realizowanych na gruncie psychiatrii, a w szczególności do prac prowadzonych przez Marię Orwid, a później - przez jej wychowanków. Była ona uczestniczką tzw. programu oświęcimskiego, który został zainicjowany w 1959 roku przez doktorów Stanisława Kłodzińskiego i Antoniego Kępińskiego przy krakowskiej Katedrze Psychiatrii ${ }^{5}$. Jego celem było wypracowanie profesjonalnych form pomocy byłym więźniom obozów koncentracyjnych. Systematyczne badania ukierunkowane na ofiary Zagłady podjął zespół stworzony przez Marię Orwid w latach 1989-1992, przy czym niemal jednocześnie

M. Hirsch, Family Pictures. Maus, Mourning and Post-Memory, „Discourse” 1992-1993, Vol. 15, nr 2, s. 4 .

2 Traumę kolektywną definiuje się jako urazy psychiczne przeżywane jednocześnie przez wielu ludzi, przy czym podstawa tego przeżycia jest wspólna. Składające się na tę zbiorowość jednostki łączy to, że są ofiarami. M. Orwid, Trauma, Kraków 2009, s. 11-13.

3 M. Hirsch, The Generation of Postmemory, „Poetics Today” 2008, Vol. 29, nr 1, s. 107, [online] https:// doi.org/10.1215/03335372-2007-019.

4 Zob. G. Weissman, Fantasies of Witnessing. Writing and Visual Culture after the Holocaust, New York 2004; R. Crownshaw, The Afterlife of Holocaust Memory in Contemporary Literature and Culture, Basingstoke 2010, Palgrave Macmillan Memory Studies; B. Sarlo, Tiempo Pasado. Cultura de la memoria y giro subjetivo. Una discusión, Buenos Aires 2005.

5 M. Orwid, Przeżyć... i co dalej?, rozmawiają K. Zimmerer, K. Szwajca, Kraków 2006, s. 159. 
zaczęto przeprowadzać wywiady również z dziećmi Ocalonych ${ }^{6}$. Praca w grupie, w której znaleźli się zarówno rodzice, jak i dzieci, ujawnita gtęboka więź międzypokoleniowa, wyrażająca się z jednej strony, wnadmiernym poczuciu odpowiedzialności dzieci za życie, szczéście i spokój rodziców, a z drugiej - wolbrzymiej koncentracji rodziców na życiu swoich dzieci $i^{7}$. W wyniku badań dostrzeżono powtarzający się w wielu rodzinach schemat: Ocaleni, świadomi swoich problemów emocjonalnych, chcąc chronić dzieci przed traumą, nie rozmawiali z nimi o wojennych przejściach. Tymczasem dzieci na ogół zdawały sobie sprawę z istniejących w rodzinie niepokojów, nawet jeśli są one pomijane milczeniem. Tajemnica $w$ rodzinie rodzi le $k^{8}$, bo ze sprawami niewyjaśnionymi i nienazwanymi dzieci nie umieją sobie radzić. Klimat tych domów Orwid określała jako „emocjonalnie trudny", ponieważ pod pozorami zwyczajności i normalności ukrywaty się niejasne i nieokreślone napięcia i tajemnice ${ }^{9}$. Do złamania tabu dochodziło zazwyczaj, gdy rodzice uznawali, że ich dzieci są wystarczająco dojrzałe ${ }^{10}$, czyli w okresie adolescencji, w którym młody człowiek zaczyna budować własną tożsamość. Wyniki badań wykazały, że dla pokolenia potomków Ocalonych centralne w tym procesie stało się doświadczenie traumy wojennej, a konkretnie lojalność wobec tych, którzy cierpieli wokresie Holocau$s t u^{11}$. Doświadczeniem pokoleniowym dla przedstawicieli drugiej generacji okazał się, podobnie jak dla ich rodziców, Holokaust, a podstawowym wyróżnikiem to, że świat, jaki znają, to świat po Zagładzie ${ }^{12}$.

W świetle ustaleń psychiatrów, opartych na wieloletnich badaniach empirycznych, trudno negować istnienie takiego zjawiska jak postpamięć, zarówno w sferze przeżyć indywidualnych, jak i zbiorowych.

Omawiane pojęcie powstało, by scharakteryzować specyficzne doświadczenia dzieci Ocalonych z Zagłady, jednak jego zakres stopniowo powiększał się i, zgodnie z sugestią Hirsch, znajduje zastosowanie w badaniach nad sytuacją każdego społeczeństwa posttotalitarnego.

6 Badania te prowadzono w ramach programu „Judaica”, kierowanego przez profesora Józefa Gierowskiego, twórcę pierwszego w Polsce Zakładu Historii i Kultury Żydów. Pamięć trzeba otworzyć, z profesor Marią Orwid rozmawia Ewa Koźmińska-Frejlak, „Midrasz” 2005, Vol. 7-8, s. 21.

M. Orwid, Przeżyć..., s. 279.

8 Pamięć trzeba otworzyć, s. 20.

M. Orwid, Przeżyć..., s. 281.

10 Tamże, s. 283.

11 Tamże, s. 285.

12 Pamięć trzeba otworzyć, s. 18. Ponadto udało się wyodrębnić zespół objawów nerwicowych, typowych dla postpokolenia w młodym wieku, takich jak silny związek z rodzicami, objawiający się lękiem separacyjnym, trudności adaptacyjne w szkole i przedszkolu, częste choroby somatyczne, samotność, dojrzałość ponad wiek. Z kolei życie dorosłe przedstawicieli drugiej generacji cechowało się nieustabilizowanym życiem osobistym, trudnościami w nawiązywaniu kontaktów społecznych, zwłaszcza z płcią przeciwną, częstszymi niż w innych grupach rozwodami i niesformalizowanymi relacjami, poczuciem osamotnienia i izolacji, tzw. lękiem uogólnionym, trudnościami w bliskości partnerskiej, skłonnością do depresji, poczuciem winy i krzywdy oraz nieadekwatną do poziomu wykształcenia, to jest zbyt niską, pozycją zawodową. Przeżyć..., s. 285-286. 


\section{POWIEŚĆ JAKO JEDEN Z PRZEJAWÓW POSTPAMIĘCI}

Postpamięć znajduje odzwierciedlenie w różnych obszarach ludzkiej aktywności. Przejawia się na przykład na poziomie społeczności lokalnych, gdy młodzi ludzie szukają śladów dawnych mieszkańców, których wspomnienie zamazało się lub zostało wyparte, jak działo się często w przypadku ludności żydowskiej ${ }^{13}$. Dziedziczone traumy odzwierciedlają się także w różnych sferach działalności artystycznej: sztukach plastycznych, architekturze, filmie, teatrze, a także w literaturze.

Polskie postpokolenie odczuwa potrzebę wyrażenia nienazwanych wcześniej urazów lub wręcz widzi w ekspresji tłumionych długo uczuć rodzaj autoterapii. Krakowskie badania wykazały, że strategia niemówienia o traumach wojennych dominowała w rodzinach Ocalonych, co więcej, to milczenie rozciągało się na ich powojenne historie: Opowieść o życiu po Holocauście to zwykle historia lakoniczna, niedopowiedziana, ledwo naszkicowana ${ }^{14}$. Podobne problemy z ekspresją własnych uczuć i przeżyć miewają przedstawiciele generacji dzieci, stąd Krzysztof Szwajca nazywa je „pokoleniem, które uczy się mówić”' 15 a Maria Orwid powtarza za Imre Kertészem tezę o potrzebie otwarcia pamięci ${ }^{16}$.

Trzeba jednak mieć na uwadze, że postpamięcią nie są obarczone wyłącznie dzieci Ocalonych z Zagłady, ale także potomkowie tych, którzy w czasie wojny występowali w rolach katów lub świadków. Oni także w różny sposób opowiadają swoje historie. To grupa dużo większa niż potomkowie Ocalonych, których liczbę szacuje się na nie więcej niż kilkaset osób ${ }^{17}$. Innymi słowy, we współczesnej Polsce nie trzeba mieć korzeni żydowskich, by odczuwać potrzebę zmierzenia się z traumą Holokaustu. Zagłada ciągle znajduje się w centrum zbiorowej świadomości, mimo upływu lat pamięć o niej nie chce zniknąć ani nie pozwala się wytłumić18. Tkwi w sercu kultury posttraumatycznej jako uraz zadawniony i wyparty, który niespodziewanie powraca i poddaje rewizji aktualna rzeczywistośs $1^{19}$.

13 Przykładem może być projekt „Światło pamięci przywraca życie... Żydowski Pejzaż Grodziska Wielkopolskiego”, zrealizowany przez licealistów z Zespołu Szkół im. Jana Pawła II w Ptaszkowie w roku szkolnym 2013/2014, [online] http://www.eszkola-wielkopolska.pl/eszkola/projekty/ gimnazjum-ptaszkowo/szalom, 15 I 2016.

14 K. Szwajca, Problemy tożsamości u dzieci ofiar Holocaustu, [online] http://dzieciholocaustu.org.pl/ szab3.php?s=ostatni_szwajca.php, 10 I 2016. Autor ilustruje tę myśl przykładem: Oto typowe zakończenie wojennej opowieści ocalonego: Po ukończeniu studiów wysztam za mąz i wyjechatam na Ślask, gdzie caty czas pracowatam jako ekonomistka w zaktadzie przemystowym. Mam dwie wspaniate córki, obie ukończyty wyższe studia, czworo wnucząt. W 1995 roku rozwiodtam się z mężem. Od 1992 roku jestem emerytka.

15 K. Szwajca, Pokolenie, które uczy się mówić, „Midrasz” 2005, Vol. 7/8, s. 40.

16 Pamięć trzeba otworzyć, s. 17.

17 K. Szwajca, Problemy tożsamości u dzieci ofiar Holocaustu.

18 K. Bojarska, Historia Zagtady i literatura niepiękna. „Tworki” Marka Bieńczyka w kontekście kultury posttraumatycznej, „Pamiętnik Literacki” 2008, R. 48, nr 2, s. 95.

19 Tamże, s. 91. 
Ponadto polska postpamięć nie musi wcale dotyczyć wyłącznie traum związanych bezpośrednio z Zagładą, przeżywanych z pozycji ofiary, świadka lub współwinnego. Doświadczenia wojenne dotknęły każdą rodzinę w Polsce i, z uwagi na sytuację polityczną i grożące poważne represje za udział w konspiracji powiązanej z rządem londyńskim, długo nie były przedmiotem rozmów nawet w środowisku najbliższych. Katyń, powstanie warszawskie, przynależność do Armii Krajowej stanowiły tematy tabu. W wielu domach zaczęto otwarcie mówić o tych sprawach dopiero po 1980 roku, a nawet u progu kolejnego dziesięciolecia, czyli wraz z odrodzeniem się niepodległego państwa.

Warto o tym pamiętać, choćby po to, by nie doszukiwać się za wszelką cenę tematyki Zagłady w każdym utworze, który w jakiś sposób nawiązuje do przeszłości. Przykładem takiej nadinterpretacji jest artykuł Anny Mach, w którym autorka, wbrew jawnie wyartykułowanym intencjom autora, czyta powieść Weiser Dawidek Pawła Huellego jako książkę o antysemityzmie i Holokauście ${ }^{20}$.

Tymczasem w prowadzonych w Krakowie w latach 60. badaniach oświęcimskich nie różnicowano doświadczeń ofiar ze względu na ich pochodzenie: Nikt nawet nie zastanawiat się nad tym, żeby w naszych badaniach poruszać sprawy narodowościowe. By dzielić cierpienie na żydowskie i nieżydowskie ${ }^{21}$. Refleksja nad specyfiką doświadczenia żydowskiego przyszła później. Dziś także niektórzy badacze przestrzegają przed absolutyzowaniem własnego cierpienia, które wyraża się słowami: moja trauma jest większa od twojej, i które w ostatecznym rachunku służy do obrony systemu wartości uważanego za jedynie słuszny ${ }^{22}$.

Trzeba na koniec dodać, że do traumatycznych doświadczeń będących konsekwencjami II wojny światowej należy zaliczyć niechciane zmiany miejsca zamieszkania, do których dochodziło z różnych powodów: np. utraty domu i bliskich, poszukiwania pracy i lepszych warunków życia, ale także w wyniku tzw. repatriacji z ziem, które znalazły się w granicach Związku Radzieckiego, lub przymusowych przesiedleń. Jednym z efektów przesunięcia granic Polski na zachód było to, że wielu migrantów znalazło się na terenach zamieszkałych przed wojną przez ludność niemiecką. Przeszłość tych obszarów była pomijana w oficjalnym dyskursie, który promował tezę o powrocie Polaków na stare ziemie piastowskie. Jednak prędzej czy później nowi mieszkańcy tych terenów musieli się skonfrontować z trudnymi pytaniami: kto był tu przed nami? Kim byli właściciele domów, w których mieszkamy? Jakie mamy prawo, by tu żyć? Znamienne jest, że z tymi pytaniami zmierzyli się dopiero przedstawiciele drugiego pokolenia, to oni również upomnieli się o wyciągnięcie z niebytu przedwojennej historii tych ziem.

20 A. Mach, Ktopotliwa (nie)pamięć o Zagtadzie. Wymazywanie żydowskości w recepcji i ekranizacji „Weisera Dawidka” Pawta Huellego, „Rocznik Komparatystyczny - Komparatistisches Jahrbuch” 2014, s. 332-351.

$21 \quad$ M. Orwid, Przeżyć..., s. 167.

22 A.D. Moses, Empire, Colony, Genocide. Conquest, Occupation, and Subaltern Resistance in World History, New York-Oxford, 2010, s. 6. 
Jeśli się weźmie to wszystko pod uwagę, nie będzie dziwić, że polska proza podejmująca tematykę postpamięciową jest bardzo obfita. Nie ma tu miejsca na katalog nazwisk i tytułów ${ }^{23}$. Warto jednak podkreślić, że debata wokół wojennej i powojennej przeszłości wcale się nie skończyła i rozwija się, zarówno na płaszczyźnie literackiej, jak i krytycznoliterackiej, mimo że do głosu doszła już trzecia generacja.

Na język hiszpański zostały przełożone, jak dotąd, trzy polskie powieści zaliczane do nurtu postpamięciowego (zob. tabela poniżej). Wszystkie zostały wydane w Hiszpanii. Przedmiotem mojej refleksji nie jest jednak tłumaczenie jako takie i jego ocena ani skuteczność obranych strategii translatorskich. Chciałabym zwrócić uwagę na okoliczności odbioru tych książek w kulturze docelowej. Interesują mnie przede wszystkim te cechy kontekstu recepcji, które wyraźnie odróżniają go od kontekstu rodzimego i, w konsekwencji, mogą wpłynąć na reinterpretację przywołanych utworów przez czytelników przekładu. Innymi słowy, zamierzam opisać warunki, jakie determinują przyjęcie elementów polskiej postpamięci w diametralnie innym kontekście kulturowym.

\begin{tabular}{|c|c|c|c|c|c|c|}
\hline Autor & $\begin{array}{c}\text { Tytul } \\
\text { oryginału }\end{array}$ & $\begin{array}{c}\text { Rok } \\
\text { wydania }\end{array}$ & Tłumacz(e) & $\begin{array}{c}\text { Tytuł } \\
\text { hiszpański }\end{array}$ & $\begin{array}{c}\text { Rok wydania } \\
\text { przekładu }\end{array}$ & $\begin{array}{c}\text { Wydawnictwo } \\
\text { przekładu }\end{array}$ \\
\hline $\begin{array}{c}\text { Paweł } \\
\text { Huelle }\end{array}$ & $\begin{array}{c}\text { Weiser } \\
\text { Dawidek }\end{array}$ & 1987 & $\begin{array}{c}\text { Pilar Gil } \\
\text { Cánovas }\end{array}$ & $\begin{array}{c}\text { iQuién } \\
\text { es Weiser } \\
\text { Dawidek? }\end{array}$ & 1991 & Seix Barral \\
\hline $\begin{array}{c}\text { Stefan } \\
\text { Chwin }\end{array}$ & $\begin{array}{c}\text { Hane- } \\
\text { mann }\end{array}$ & 1995 & $\begin{array}{c}\text { Jerzy } \\
\text { Sławomirski } \\
\text { i Ana Rubió }\end{array}$ & $\begin{array}{c}\text { Eldoctor } \\
\text { Hanemann }\end{array}$ & 2005 & Acantilado \\
\hline $\begin{array}{c}\text { Marek } \\
\text { Bieńczyk }\end{array}$ & Tworki & 1999 & $\begin{array}{c}\text { Maila Lema } \\
\text { Quintana }\end{array}$ & $\begin{array}{c}\text { Tworki(El } \\
\text { manicomio })\end{array}$ & 2010 & Acantilado \\
\hline
\end{tabular}

Wszyscy wymienieni autorzy urodzili się po wojnie (Huelle ur. 1947, Chwin ur. 1949, Bieńczyk ur. 1956), są zatem reprezentantami postpokolenia. Dwie pierwsze książki, których akcja rozgrywa się w powojennym Gdańsku, są rodzajem zapisu zmagań młodych bohaterów z niejasną i tajemniczą atmosferą miasta, zawieszonego między dwoma kulturami. Bieńczyk natomiast w nowatorski sposób podejmuje temat Zagłady, świadomie podkreślając dystans czasowy, jaki dzieli narratora od opisywanych wydarzeń, i stawiając pytanie: jak pisać o Szoa ponad pół wieku później?

\section{PRZEKŁAD W PERSPEKTYWIE TRANSKULTUROWEJ}

Przekład literacki jest aktem ze swej istoty transgresyjnym: Sztuka przektadu powstata $z$ chęci transgresji, zrozumienia obcego i nieznanego, które uwalnia od lęku - pisała

23 Zob. np. M. Cuber, Metonimie Zagtady. O polskiejprozie lat 1987-2012, Katowice 2013, Prace Naukowe Uniwersytetu Śląkiego w Katowicach, nr 3027; A. Ubertowska, Świadectwo, trauma, gtos. Literackie reprezentacje Holokaustu, Kraków 2007, Modernizm w Polsce, t. 16. 
Bożena Tokarz ${ }^{24}$. Przez transgresję rozumie się postawe prowadzaca do podejmowania wyzwań, pokonywania barier, przekraczania granic ${ }^{25}$.

Transgresja kultury polega na dążeniu do przesuwania granic akceptacji form ekspresji. Dlatego działania o charakterze transgresyjnym mogą być postrzegane jako wyzwanie dla obowiązujących norm i wartości, a nawet - ponieważ kwestionują kanony etyczne i estetyczne - jako zagrożenie dla zastanego systemu kulturowego. Nie jest dziwne zatem, że niekiedy prowokują krytyczne, wręcz obronne, reakcje. Konsekwencje aktów transgresji bywają różne, zarówno pozytywne, jak i negatywne. Mogą one zatem prowadzić do otwarcia się na przestrzeń odmiennego obszaru kulturowego, mogą także spowodować odrzucenie, a w efekcie - zmarginalizowanie i alienację.

Nośnik transgresji, jakim jest przekład, przekroczywszy barierę obcej kultury, ma szansę wprowadzenia w jej obszar nowych form literackich, czyli „odświeżenia repertuaru”, jak powiedziałby Itamar Even-Zohar ${ }^{26}$, wzbogacenia jej nowymi treściami, wreszcie - zadomowienia się w niej, czyli, by ponownie odwołać się do teorii polisystemów, przekształcenia się w element systemu kultury przyjmującej. Może się jednak zdarzyć i tak, że ładunek obcości, jaki dany przekład niesie ze sobą na płaszczyźnie formalnej bądź treściowej, jest tak duży, że okaże się nie do przyjęcia dla członków docelowej wspólnoty kulturowej, co spowoduje jego odrzucenie i zepchnięcie na peryferie systemu.

Na przekład prozy postpamięciowej można spojrzeć z jeszcze innej perspektywy. W ramach dynamicznie rozwijających się badań nad pamięcią zaczyna się mówić o jej transkulturowym wymiarze. Zwraca się uwagę na to, że artefakty będące jej nośnikami mogą być przenoszone w kontekst kulturowy - czasowy lub przestrzenny - dla którego nie były pierwotnie przewidziane. Ten nowy kontekst dopisuje im znaczenia, uwalnia kolejne interpretacje. Zjawisko to bywa też nazywane "pamięcią w podróży” (travelling memory $)^{27}$.

Przykładem tego, w jaki sposób pamięć nabiera transkulturowych znaczeń, jest historia Babi Yar Park w Denver, krajobrazowego monumentu zbudowanego, by upamiętnić masowe egzekucje głównie ludności żydowskiej wykonywane przez Niemców podczas II wojny światowej w podkijowskim wąwozie. Powodem zlokalizowania pomnika w Kolorado była nie tylko potrzeba wyrażana przez żyjącą tam dużą wspólnotę osób pochodzenia ukraińskiego, ale także domniemane podobieństwo

24 B. Tokarz, Tabu i autocenzura w przektadzie, [w:] Tabu w przektadzie, red. P. Fast, N. Strzelecka, Katowice 2007, s. 7, Studia o Przektadzie, nr 23.

25 T. Paleczny, Transgresja jako nastepstwo kontaktu kulturowego, [w:] Transgresja w kulturze, red. T. Paleczny, J. Talewicz-Kwiatkowska, Kraków 2014, s. 9, Varia Culturalia.

26 I. Even-Zohar, Miejsce literatury ttumaczonej w polisystemie literackim, przeł. M. Heydel, [w:] Wspótczesne teorie przektadu. Antologia, red. P. Bukowski, M. Heydel, Kraków 2009, s. 195-203.

27 Termin ten ma syntetycznie opisywać zjawisko polegające na tym, że ludzie, media, treści i działania zaangażowane w tworzenie pamięci kulturowej znajdują się w nieustannym ruchu, w podróży przez czas i przestrzeń, w poprzek wszelkich - politycznych, społecznych i językowych granic. A. Earl, A. Rigney, Travelling Memory, „Parallax” 2011, Vol. 17, nr 4, s. 11-12, [online] https://doi.org/10.10 $80 / 13534645.2011 .605570$. 
lokalnego krajobrazu do parowu, w którym rozstrzeliwano więźniów. W czasach zimnej wojny w Babi Yark Park widziano także symbol protestu przeciw działaniom sowieckiego reżimu na Ukrainie. W XXI wieku umieszczono tam fragment żelaznej konstrukcji odzyskanej z ruin World Trade Center, by uczcić ofiary zamachu z 11 września 2001 roku. Nadało to pomnikowi ukraińskiej tragedii nowe funkcje: wyrażania wzajemnej empatii ukraińskiej społeczności w Denver i mieszkańców Nowego Jorku, okazywania wspólnoty w cierpieniu bez względu na pochodzenie, wreszcie - podkreślenia roli międzynarodowej solidarności ${ }^{28}$. Jednak taką ingerencję w przestrzeń pomnika można postrzegać również jako wyraz braku szacunku dla uczuć przedstawicieli innych kultur i próbę narzucenia im amerykańskiego punktu widzenia przez gloryfikację własnej tragedii ${ }^{29}$. Innymi słowy, byłaby to demonstracja władzy w przestrzeni symbolicznej ${ }^{30}$.

Tłumaczenia utworów literackich o tematyce postpamięciowej wydają się niemal prototypowymi przykładami pamięci w podróży. Już sam termin „postpamięć” konotuje znaczne przesunięcie czasowe, jednoznacznie sugerując, że chodzi o traumy zadawnione. Przekład i wydanie takiej książki w innym kraju powoduje przemieszczenie przestrzenne tej pamięci. Pierre Bourdieu wskazywał, że tłumaczone utwory nie przenoszą z sobą kontekstu, w jakim powstały, w związku z tym zostają odarte ze znaczeń, które ten kontekst wnosił do ich rozumienia. Wrzucone w inną sytuację odbioru, nabierają nowych sensów, w skrajnym przypadku sprzecznych z intencjami autora ${ }^{31}$.

Przetłumaczona proza postpamięciowa zderza się w kulturze docelowej z cudzą pamięcią, odwołującą się do innych zdarzeń i doświadczeń, mniej lub bardziej traumatyczną, w mniejszym lub większym stopniu przepracowaną. W rezultacie może doczekać się nieoczekiwanych, zaskakujących interpretacji, zmodyfikować spojrzenie odbiorców przekładu na własną pamięć, może także pozostać niezrozumiała i w konsekwencji - odrzucona.

Pierwszym krokiem do badań nad postpamięcią, której podróż w przestrzeni realizuje się za pomocą przekładu literackiego, jest próba opisania różnych wymiarów i aspektów kontekstu docelowego. Istotnymi elementami tego kontekstu są: wiedza odbiorców o świecie, o jakim mówi dany utwór, wiedza o systemie literackim, w jakim powstał, a także istnienie lub brak w kulturze docelowej paralelnych schematów literackich oraz pokrewnych form wyrażania pamięci.

28 L. Bond, J. Rapson, Introduction, [w:] The Transcultural Turn. Interrogating Memory Between and Beyond Borders, red. J. Rapson, L. Bond, Berlin 2004, s. 3-4.

Tamże, s. 7.

30 Tu nieuchronnie przychodzą na myśl skojarzenia z działaniami Ministerstwa Obrony Narodowej. Na organizatorach uroczystości upamiętniających święta narodowe próbuje się wymusić czytanie w ich trakcie tzw. apelu smoleńskiego, po to, by narzucić własną narrację. W tym przypadku zasadniczym celem jest nie tyle inne odczytanie znaczenia danego święta, ile gloryfikowanie ofiar katastrofy prezydenckiego samolotu przez zrównanie ich z bohaterami wojen lub powstań. To typowy akt przemocy symbolicznej.

31 P. Bourdieu, Les conditions sociales de la circulation international des idées, „Actes de la recherche en science sociales" 2002, nr 5, s. 3-8, [online] https://doi.org/10.3917/arss.145.0003. 


\section{WIEDZA HISZPANÓW O RZECZYWISTOŚCI WOJENNEJ W POLSCE}

Zrozumienie tekstu polega na uchwyceniu jego spójności, co literaturoznawcy i językoznawcy zgodnie określają jako zdolność odbiorcy do powiązania z tekstem odpowiednich elementów rzeczywistości pozajęzykowej ${ }^{32}$. Odbiorca przekładu jest w stanie śledzić strukturę tekstu i rozszyfrować występujące w nim elementy znaczeniowe, jeśli ten tekst odwołuje się do informacji, jakie czytelnik posiada na temat kultury wyjściowej lub do wyobrażeń o niej ${ }^{33}$. Dlatego tak ważne jest, by badając recepcję utworów literackich jawnie nawiązujących do rzeczywistych wydarzeń, określić, jaki jest stan wiedzy docelowego czytelnika na ich temat.

Na początek trzeba podkreślić zasadniczą różnicę doświadczeń historycznych, jakie były udziałem społeczności hiszpańskiej i polskiej w latach 30. i 40. XX wieku. Hiszpanie przeżyli koszmar wojny domowej lat 1936-1939, ale, mimo że generał Franco wspierał III Rzeszę, zawierał z nią umowy o współpracy wojskowej, wywiadowczej i gospodarczej, tzw. Państwo Hiszpańskie (Estado Español) nigdy nie zaangażowało się bezpośrednio w II wojnę światową. Lata 1945-1953 były okresem niemal całkowitej izolacji Hiszpanii na arenie międzynarodowej. Z krajami bloku komunistycznego kraj ten nie utrzymywał stosunków dyplomatycznych ani kulturalnych. Represyjna cenzura skutecznie blokowała wymianę literacką. W oficjalnym dyskursie III Rzeszę i jej działania ukazywano w możliwie dobrym świetle ${ }^{34}$. Nie było w nim miejsca na Zagładę Żydów, obozy koncentracyjne, stosunek Niemców do mieszkańców krajów okupowanych. Stopniową zmianę tej sytuacji można było zaobserwować po śmierci generała Franco i transformacji ustrojowej, która po niej nastąpiła. Jednak z niektórymi sprawami przeciętny Hiszpan miał okazję skonfrontować się dopiero w XXI wieku. Dotyczy to m.in. Zagłady Żydów. Wiedza o Szoa zaczęła stopniowo przedzierać się do powszechnej świadomości dopiero pod koniec lat 60. ubiegłego stulecia, a najważniejsze teksty na jej temat, literackie i dokumentalne, zaczęto wydawać dopiero na przełomie wieków.

Dzisiaj Hiszpanie czerpią informacje o II wojnie światowej przede wszystkim z podręczników szkolnych. Siłą rzeczy prezentują one obraz syntetyczny, koncentrujący się na najważniejszych faktach i na najważniejszych graczach. Polskę wymienia się w nich jedynie w kontekście inwazji na jej ziemie, która rozpoczęła wojnę. Tematyka Zagłady jest poruszana, z badań jednak wynika, że jest prezentowana w formie „aseptycznej" narracji relacjonującej suche fakty i eksponującej logikę tzw. ostatecznego rozwiązania kwestii żydowskiej, natomiast brakuje w niej głosu ofiar ${ }^{35}$. W konsekwencji

32 Encyklopedia jezykoznawstwa ogólnego, red. K. Polański, Wrocław 1995, s. 505; J. Lalewicz, Semantyczne wyznaczniki lektury, [w:] Problemy odbioru i odbiorcy, red. T. Bujnicki, J. Sławiński, Wrocław 1977, s. 10, Z Dziejów Form Artystycznych w Literaturze Polskiej, t. 47.

33 C. Karolak, Problemy odbioru tekstu literackiego w warunkach obcokulturowych, „Lingua ac Communitas" 1999, Vol. 9, s. 139.

34 J.R. Richart, Literatura española de tema alemán (siglo XX), [online] http://cvc.cervantes.es/literatura/aih/pdf/09/aih_09_2_039.pdf, 25 VII 2015.

35 http://mugak.eu/revista-mugak/no-49/grupo-eleuterio-quintanilla-pensad-que-esto-ha-sucedido-una-propuesta-didactica-sobre-el-holocausto, 18 I 2016. 
wiedza przeciętnego Hiszpana o II wojnie światowej jest silnie zestereotypizowana i podporządkowana logice przyczynowo-skutkowej. Nie jest on jednak świadom, na przykład, różnic w sytuacji mieszkańców państw znajdujących się pod niemiecką okupacją.

\section{LITERATURA POLSKA W HISZPANII}

Wiedzę o świecie można czerpać, oczywiście, nie tylko z podręczników szkolnych i mediów, ale także z utworów literackich. Tłumaczenia tekstów artystycznych, zwłaszcza prozy, dostarczają zarówno informacji o kraju, z jakiego pochodzą, jak i kształtują pewną wizję jego kultury. Dlatego istotne staje się pytanie, czy dzieła polskich autorów zostały przetłumaczone na hiszpański (a jeśli tak, to których), czy wydano je w Hiszpanii i czy zaistniały w tamtejszej kulturze literackiej. Innymi słowy, warto sprawdzić, czy w Hiszpanii powstał kanon literatury polskiej i, ewentualnie, jakie utwory się nań składają.

Do czasu wybuchu wojny domowej trudno mówić o obecności literatury polskiej w Hiszpanii, skoro niemal jedynym pisarzem, którego książki publikowano, był Henryk Sienkiewicz ${ }^{36}$, a przekłady jego utworów, wykonywane niebezpośrednio, ale za pośrednictwem wcześniejszych tłumaczeń francuskich, były niskiej jakości. W okresie dyktatury generała Franco cenzura skutecznie blokowała publikacje, których autorzy pochodzili z krajów bloku komunistycznego, dlatego nieliczne książki polskich pisarzy wówczas wydawane wychodziły spod pióra twórców przebywających na emigracji, takich jak Sergiusz Piasecki, Józef Mackiewicz czy Witold Gombrowicz. Pod koniec lat 70., po upadku dyktatury generała Franco, wydawcy, aby nadrobić zaległości, zaczęli publikować współczesną klasykę światową, a także poszerzali ofertę, próbując zainteresować czytelników literaturą krajów, których kultura była w Hiszpanii mało znana ${ }^{37}$. Skorzystała na tym także proza polska, na rynek wydawniczy stopniowo zaczęto wprowadzać dzieła najważniejszych pisarzy międzywojennych: Brunona Schulza, Stanisława Witkiewicza, Jarosława Iwaszkiewicza, a później również utwory autorów młodszej generacji, Andrzeja Szczypiorskiego i Jerzego Andrzejewskiego $^{38}$. Na przełomie XX i XXI wieku pojawiły się także pojedyncze książki pisarzy, którzy zaczęli święcić sukcesy po transformacji ustrojowej: Panna Nikt Tomka Tryzny (1998), Kabaret metafizyczny Manueli Gretkowskiej (2000), Prawiek Olgi Tokarczuk (2001), Madame Antoniego Libery (2002), Wojna polsko-ruska pod flagq biato-czerwona Doroty Masłowskiej (2005), Dukla (2003), Dziewięć (2004) Andrzeja Stasiuka, Inne rozkosze Jerzego Pilcha (2005). Trudno jednak mówić, by zdobyły

36 B. Zaboklicka, Literatura polska w Hiszpanii. Obecna, choć nieznana, [w:] Polonistyka bez granic, t. 1: Wiedza o literaturze i kulturze, red. R. Nycz, W. Miodunka, T. Kunz, Kraków 2010, s. 576.

37 Tamíe, s. 573.

38 Obszerne informacje dotyczące obecności literatury polskiej w Hiszpanii okresu dyktatury znajdzie czytelnik w opracowaniu Ilony Narębskiej Literatura polaca en España (1939-1975). Autores, editores, traductores, Wrocław 2015, Biblioteka Iberoromańska, t. 1. 
duży rozgłos. Tłumaczono na język hiszpański również polską poezję współczesnąą ${ }^{39}$, ale trzeba pamiętać, że czytelnicy poezji stanowią stosunkowo wąską grupę odbiorców. O pewnej popularności można mówić w przypadku dwojga noblistów: Czesława Miłosza i Wisławy Szymborskiej.

Prawdziwy sukces odnieśli w Hiszpanii tylko dwaj pisarze: Stanisław Lem i Ryszard Kapuściński, a spośród autorów literatury popularnej - Andrzej Sapkowski. W sumie jednak literatura polska pozostaje tam zjawiskiem niszowym. Wydania książek polskich autorów są postrzegane jako wydarzenia odosobnione, hiszpańscy czytelnicy nie są w stanie usytuować ich na tle innych utworów, bo ich po prostu nie znają. Czytelnicy zapoznaja się z dzietem Gombrowicza, Lema czy Kapuścińskiego, ale nie mają wizji kultury, do której ci autorzy przynależa, tak jak ją mają w przypadku Shakespeare’a czy Bal$z a c a^{40}$. Kanon literatury polskiej po prostu w Hiszpanii nigdy nie powstał.

Nie wspomniałam dotąd o przekładach na język hiszpański polskiej prozy wojennej, ponieważ ze względu na temat tego artykułu warto tę kwestię omówić oddzielnie.

Wiedza o Zagładzie staje się powszechna w Hiszpanii dopiero w bieżącym stuleciu. Ogromną rolę odegrał w jej popularyzacji wydawca, Mario Muchnik, z pochodzenia Argentyńczyk, który w latach 60. zainicjował wprowadzanie na rynek utworów zaliczanych do klasyki literatury Holokaustu, gatunku nieistniejącego wcześniej w hiszpańskim systemie literackim ${ }^{41}$. To on pozyskał prawa autorskie do książki Primo Leviego Czy to jest cztowiek i opublikował jej przekład nakładem oficyny Muchnik Editores w $1987 \mathrm{roku}^{42}$, co okazało się kamieniem milowym w recepcji literatury Holokaustu w Hiszpanii.

Książki polskich twórców dotyczące II wojny światowej, w tym Zagłady, zaczęły ukazywać się w Hiszpanii dopiero w pierwszej dekadzie XXI wieku. Wcześniej opublikowano jedynie pojedyncze tytuły, napisane przez autorów powiązanych z rządem londyńskim i przebywających na emigracji. Wśród nich były, na przykład, Bez ostatniego rozdziatu generała Władysława Andersa (1948) i Katyń. Zbrodnia bez sadu i bez kary Józefa Mackiewicza (1950) ${ }^{43}$.

Tłumaczenia utworów pisarzy mieszkających w Polsce wydano w Hiszpanii dopiero w bieżącym stuleciu, na fali rosnącej popularności europejskiej literatury wojennej, zwłaszcza dotyczącej Holokaustu. I tak np. przekład Dymów nad Birkenau Seweryny

39 Mam tu na myśli nie tylko publikacje rozproszone w czasopismach, ale także antologie, np. Antología de la poesía polaca pod red. Fernanda Presy Gonzálesa (2006) czy Poesia a contragolpe. Antología de la poesía polaca contemporánea w wyborze Abela Murcii i in. (2012). Te obszerne wybory pojawiły się jednak dopiero w XXI wieku.

B. Zaboklicka, Literatura polska w Hiszpanii..., s. 579.

41 L. Alonso, X.M. Garrido Villariño, Paratraductores de la literatura del Holocausto en castellano, [w:] Traducción. Contextos e implicaciones, red. M. Gaszyńska-Magiera, J.C. Nowicka, Wrocław 2014, s. 43-44.

42 Tamże, s. 47. Książka tę wydano po raz pierwszy we Włoszech w 1947 roku pod tytułem Se questo è un nomo. Tytuł hiszpański brzmi: Si esto es un hombre.

43 J. Wyszyńska, Situación de la literatura polaca sobre la Segunda Guerra Mundial en España, [w:] Ideologias en traducción. Literatura, didáctica, cultura, red. I. Kasperska, L.I. Villegas, A.D. Mendia, Frankfurt am Main 2016, s. 252. 
Szmaglewskiej opublikowano w 2006 roku, czyli prawie 60 lat później niż oryginal ${ }^{44}$, z jeszcze większym przesunięciem czasowym wyszedł hiszpański przekład Medalionów Zofii Nałkowskiej (2009). Pamiętnik z powstania warszawskiego Mirona Białoszewskiego ukazał się w Hiszpanii w 2011 roku. Dopiero książki napisane współcześnie, jak np. I byta mitość w getcie Marka Edelmana (2009) czy Oskarżona. Wiera Gran Agaty Tuszyńskiej (2010) wydano niemal natychmiast: odpowiednio w 2013 i 2011 roku. Wymienione tytuły są postrzegane w Hiszpanii nie tyle jako reprezentatywne dla polskiej literatury współczesnej, ale raczej jako przykłady europejskiej prozy o II wojnie światowej ${ }^{45}$.

Podsumowując, znani w Hiszpanii autorzy, Lem i Kapuściński, szufladkowani są w potocznym odbiorze jako „wielcy pisarze”, niekoniecznie kojarzeni z Polską. Stosunkowo licznie reprezentowana polska literatura wojenna wtapia się w literaturę o tej tematyce powstałą w innych krajach europejskich. Takie książki jak Weiser Dawidek, Hanemann czy Tworki nie znajdują zatem w hiszpańskim systemie literackim układu odniesienia - z jednej strony z uwagi na brak kanonu literatury polskiej, z drugiej - na silnie zestereotypizowany, ujednolicony obraz europejskiej prozy wojennej, w którym rzadko dochodzą do głosu wątki narodowe.

\section{HISZPAŃSKA PROZA POSTPAMIĘCIOWA}

Najważniejszym tematem, wokół którego koncertowały się książki zaliczane do nurtu pamięciowego, a później postpamięciowego, była wojna domowa. Piśmiennictwo jej dotyczące, w tym wspomnienia, świadectwa, utwory literackie, jest bardzo obfite. Jednak w różnych okresach powojennej historii inne wątki wychodzity na pierwszy plan. W czasach reżimu generała Franco cenzura eliminowała z dyskursu publicznego głosy przegranych. Do publikacji dopuszczano utwory, które nie podważały oficjalnej narracji, pewne tematy nie mogły być w ogóle poruszane. W latach, które nastąpiły bezpośrednio po transformacji ustrojowej, dał się zaobserwować wysyp publikacji o wartości dokumentu, czyli różnego rodzaju wspomnień, dzienników, pamiętników. Jednak, zaskakująco, w przestrzeni publicznej głosy świadków starano się wyciszać. Tak zwane Ley de Amnistia (Prawo o amnestii) uchwalone w 1977 roku, niemal jednogłośnie, z aprobatą wszystkich partii politycznych, objęło więźniów politycznych oraz osoby odpowiedzialne za szereg przestępstw popełnionych przed rokiem 1976, takich jak bunt i protest polityczny skierowane przeciw legalnej wówczas władzy. Zatem definitywnie ułaskawiono więźniów reżimu, jednocześnie jednak zwolniono z jakiejkolwiek odpowiedzialności przedstawicieli i funkcjonariuszy dyktatury. Celem tej uchwały było utrwalenie świeżo ustalonego porządku politycznego, wyciszenie emocji, budowanie zgody, zasypywanie przepaści. Uważana za kontrowersyjną, dla jednych stanowiła akt definitywnego

44 Tu warto zaznaczyć, że przekład angielski ukazał się już w 1947 roku. Z kolei we Francji ta książka nie wyszła do dziś. Zob. J. Wyszyńska, Situación de la literatura polaca..., s. 252.

45 Świadczy o tym np. analiza treści blogów poświęconych piśmiennictwu dotyczącego problematyki II wojny światowej. Zob. M. Gaszyńska-Magiera, Una novela posmemorial en España, [w:] Ideologías en traducción..., s. 129-146. 
zerwania z dyktaturą, dla innych - niczym nieusprawiedliwione zamknięcie dyskusji o zbrodniach reżimu. W każdym razie głos tych, którzy byli pozbawieni możliwości wypowiadania się przez lata dyktatury, znów został stłumiony. Politycy wszystkich partii zgodnie postanowili, by unikać tematu wojny domowej w imię utrzymania kruchej jeszcze stabilizacji; była to polityka ciszy, nazywana „pojednaniem narodowym”. Inni mówili o pakcie milczenia (pacto de olvido), polegającym na wyeliminowaniu z debaty publicznej spraw mogących zantagonizować społeczeństwo. Jednak wielu jego członków czuło się pozbawionych głosu, prawa do opowiedzenia swoich losów lub oceny historii ze swojego punktu widzenia ${ }^{46}$. Tak więc w Hiszpanii po ustaleniu porządku demokratycznego próbowano budować model nowoczesności oparty na dobrobycie materialnym i ekonomii rynkowej, jednocześnie odwracając się od traum przeszłości.

Taki stan rzeczy utrzymywał się do lat 80 . Jednak tlący się konflikt pamięci spowodował, że pod koniec XX wieku zderzyły się - z jednej strony - głód wiedzy i pragnienie zapomnienia, $\mathrm{z}$ drugiej - wiele różnych pamięci, które wyłoniły się w konsekwencji rosnącego zainteresowania historią ${ }^{47}$.

W efekcie w pierwszej dekadzie XXI wieku nastąpił prawdziwy boom publikacji dotyczących wojny domowej, o bardzo różnym charakterze: historycznych, socjologicznych, politologicznych, teoretycznoliterackich i historycznoliterackich, a także powieści (nie zawsze najwyższego lotu) i tekstów publicystycznych ${ }^{48}$. Dyskusja zatem toczy się zarówno na płaszczyźnie naukowej, jak i literackiej. Autorzy najnowszych powieści reprezentują de facto trzecie pokolenie, które nie tylko nie może pamiętać wojny domowej, ale jest urodzone już po przełomie, zatem zna tylko czasy demokracji.

$\mathrm{Na}$ płaszczyźnie politycznej wyrazem uznania i poszerzenia prawa ofiar prześladowań i gwałtów popełnionych podczas wojny domowej i w okresie dyktatury stało się Prawo o pamięci historycznej (Ley de la Memoria Histórica) uchwalone 26 grudnia 2007 roku przez hiszpański parlament.

Zatem współcześni Hiszpanie, podobnie jak współcześni Polacy, mają swoją postpamięć, bardzo żywą, ujawniającą się w różny sposób, również w postaci tekstów literackich. Liczba tych publikacji i temperatura sporów wskazują, że wojna domowa nadal jest jednym z centralnych, „gorących” tematów współczesnej literatury ${ }^{49}$. W kontekście recepcji polskiej prozy współczesnej nasuwa się wątpliwość: czy ciągle żywa trauma wojny domowej może zostawić miejsce na zainteresowanie się cudzymi, zadawnionymi urazami?

46 E. Liikanen, Novelar para recordar. La posmemoria de la guerra civil y el franquismo en la novela española de la democracia. Cuatro casos, Congreso La Guerra Civil Española 1936-39, 2006, [online] http://www.secc.es/media/docs/33_4_LII_KANEN.pdf, 10 I 2017.

47 Tamże.

48 I. Cuñado, Despertar tras la amnesia. Guerra civil y postmemoria en la novela española del siglo XXI, „Dissidences. Hispanic Journal of Theory and Criticism” 2012, Vol. 2, nr 3, [online] http://digitalcommons.bowdoin.edu/dissidences/vol2/iss3/8, 10 I 2017.

49 Nie sposób wymienić wszystkich powieści z tego nurtu, dlatego przywołam tylko dwie, wydane w polskich przekładach: Goraczka i wtócznia Javiera Maríasa (2002, pol. 2010, przeł. E. Zaleska) i Żotnierze spod Salaminy Javiera Cercasa (2001, pol. 2005, przeł. E. Zaleska). 
Można także zastanowić się, czy, jeśli nie sama tematyka postpamięciowa, to może pewne schematy powieściowe, wypracowane w ramach nurtu zajmującego się nią, mogłyby ułatwić przyjęcie polskiej prozy postpamięciowej i jej zrozumienie. Inaczej mówiąc, warto zbadać, czy polska i hiszpańska postpamięć przejawiają się w utworach literackich w podobny sposób, tj. czy czytelnik hiszpański jest w stanie znaleźć dla polskiej powieści współczesnej jakieś punkty odniesienia w płaszczyźnie formalnej rodzimej twórczości.

W obu przypadkach powieści postpamięciowe pojawiają się w momencie, o którym mówi się w kontekście odrodzenia powieści, poszukiwania i znajdywania nowego języka, oryginalnych technik narracyjnych itp. Ta problematyka wydaje się uwalniać nowatorskie rozwiązania formalne. Ale czy podobne w obu krajach?

Polska postpamięć - przynajmniej w przywołanych w tym artykule powieściach manifestuje się nie wprost, lecz na drugim planie. Wiele w tych książkach niedomówień, aluzji, podtekstów, które można wyłapać przede wszystkim dzięki uważnej lekturze, znając kontekst historyczny i podejmując pewien wysiłek poznawczy. Łatwiej skoncentrować się na pierwszym planie, śledzić akcję - wciągającą, bo to książki sprawnie napisane - i najzwyczajniej w świecie przegapić tę warstwę, która jest ukryta, ale stanowi jeden $\mathrm{z}$ najistotniejszych elementów przesłania. Dość powiedzieć, że w Hanemannie słowo „powstanie” zostało użyte trzy razy, a to wydarzenie jest kluczowe, by zrozumieć postępowanie jednej z głównych bohaterek powieści, matki narratora. W Tworkach - w książce o Zagładzie! - słowo „żyd” pojawia się tylko raz, pisane małą literą, jako, dziś brzmiący archaicznie, synonim „kleksa”. Aby tę warstwę odkryć, trzeba czytać bardzo uważnie, dostrzegać istotne szczegóły, umieć interpretować znaczenie drobiazgów.

Weiser Dawidek i Hanemann mają wiele cech tzw. powieści o formowaniu (Bildungsroman). Ich narratorzy wracają myślami do czasów dzieciństwa i młodości, próbują zobaczyć wydarzenia sprzed lat $\mathrm{w}$ różnych perspektywach, aby odnaleźć w nich elementy brakujące do zbudowania spójnej tożsamości. Reinterpretują fakty i zapamiętane rozmowy, których sens był dla nich niejasny, starając się zrozumieć ich prawdziwe znaczenia. Konstruowanie przez bohaterów własnej tożsamości, niemożliwe bez właściwego rozpoznania trudnej historii rodzinnej i miejsc, w których im przyszło dorastać, wydaje się zasadniczym tematem tych utworów.

Tymczasem hiszpańskie powieści postpamięciowe mają inną poetykę. Jednym z często stosowanych schematów narracyjnych jest śledztwo podejmowane przez głównego bohatera, dotyczące faktów z odległej o 60-70 lat przeszłości. Bywa zainicjowane albo chęcią wyjaśnienia części rodzinnej historii, dotąd przemilczanej lub zapomnianej, albo przypadkowym odkryciem jakiejś niejasnej relacji, która wymaga dopowiedzenia, lub wydarzenia, które okazuje się istotnym elementem jakiejś historycznej układanki. Niekiedy takie powieści bazują na odnalezionych źródłach - dokumentach, czasem rzeczywistych, czasem spreparowanych na potrzeby narracji, mieszcząc się w podgatunku prozy nazwanym w Hiszpanii docuficción. Inną popularną formą prozy postpamięciowej jest także biografia albo autobiografia, oparta na faktach lub całkowicie fikcyjna ${ }^{50}$.

50 J.M. Rubio, La novela de investigación de escritor. Representaciones de la ambigüedad en la narrativa 
Częstym chwytem narracyjnym bywa narracja wieloperspektywiczna, w której głos oddaje się kilku postaciom, relacjonującym wydarzenia $\mathrm{z}$ własnego punktu widzenia, co pociąga za sobą różnorodność dyskursów, rejestrów i stylów. W konsekwencji pozostawia się czytelnikowi moralną ocenę postępowania bohaterów oraz decyzję, która z przedstawionych wersji jest najbardziej prawdopodobna ${ }^{51}$.

Kolejną ważną cechą niektórych hiszpańskich powieści nurtu postpamięciowego jest autorefleksyjność, czyli namysł nad samym procesem powstawania opowieści, niejednokrotnie prowadzący do kwestionowania obiektywności narracji i jej roli w docieraniu do prawdy ${ }^{52}$.

Na koniec trzeba wspomnieć o ciągle żywej, także w utworach podejmujących problematykę pamięci i postpamięci, konwencji realistycznej, odwołującej się wprost do uczuć odbiorcy.

W każdym przypadku jednak bez względu na rozwiązania formalne, w hiszpańskiej prozie omawianego nurtu literackiego zmaganie się z pamięcią dziedziczoną ma charakter jawny. Trudno zatem mówić o formalnym podobieństwie między polską a hiszpańską narracją postpamięciową. Nawet na tej płaszczyźnie potencjalny hiszpański czytelnik polskiej prozy nie ma się do czego odwołać.

\section{PODSUMOWANIE}

Spróbujmy zatem zreasumować, jak przedstawiają się warunki recepcji przywołanych powieści we współczesnej Hiszpanii.

W hiszpańskiej przestrzeni publicznej tematyka związana z II wojną światową i Zagładą zaczęła pojawiać się dopiero w latach 60. ubiegłego wieku, a wysyp publikacji nastąpił na przełomie stuleci. Wiedza przeciętnego hiszpańskiego odbiorcy o II wojnie światowej, w tym o realiach w krajach okupowanych przez Niemców, jest niebyt rozległa i oparta na ogół na podręcznikach szkolnych. To spojrzenie z dużej perspektywy, zarówno czasowej, jak i przestrzennej, spojrzenie z zewnątrz, z pozycji obserwatora nieobciążonego rodzinną pamięcią o tamtych wydarzeniach. W tym upatrywałabym najważniejszą różnicę między polską i hiszpańską pamięcią o II wojnie światowej: Hiszpanie nie czerpią wiedzy o niej z relacji bezpośrednich, z przekazów rodzinnych i, siłą rzeczy, nie mają do niej emocjonalnego stosunku, podczas gdy czasy okupacji nadal stanowią element polskiej świadomości, zarówno indywidualnej, jak i zbiorowej, tworząc jeden z fundamentów tożsamości.

hispánica contemporánea (2001-2012), praca doktorska, s. 153-176, [online] http://roderic.uv.es/bitstream/handle/10550/32094/La\%20Novela\%20de\%20Investigaci\%C3\%B3n\%20de\%20Escritor. pdf ? sequence=1, 26 X 2016.

51 M. Potok, Estrategias literarias para la recuperación de la memoria histórica. La narrativa actual frente a la guerra civil, „Études romanes de Brno” 2012, Vol. 33, nr 2, s. 14. W tym artykule czytelnik znajdzie również listę najważniejszych tytułów hiszpańskich powieści zaliczanych do nurtu postpamięciowego.

52 Tamże, s. 15. 
Ponadto w Hiszpanii literatura polska, i dawna, i współczesna, pozostaje nieznana. W tej sytuacji czytelnik nie ma możliwości odniesienia wciąż nielicznych, pojawiających się aktualnie przekładów do konkretnego kontekstu naszej literatury narodowej.

W Hiszpanii pamięć wojny domowej jest nadal żywa, a konieczność uporania się ze śladami, jakie zostawiła w zbiorowej psychice i rozliczenia się z historią XX wieku, znajduje wyraz również na kartach utworów literackich. To budzi podejrzenie, że cudze traumy nie są w stanie wzbudzić zainteresowania, tym bardziej że w Hiszpanii wykształcił się zupełnie inny niż w Polsce schemat powieści postpamięciowej, cechujący się bardziej eksplicytnymi środkami wyrazu.

Czy tak zarysowany kontekst sprzyja polskiej postpamięci podróżującej dzięki przekładowi literatury pięknej? Nasuwająca się w pierwszej chwili refleksja kazałaby chyba odpowiedzieć przecząco. Akt transgresji kulturowej, jakim jest przetłumaczenie na język hiszpański polskiej powieści poruszającej problematykę pamięci odziedziczonej, wydaje się ryzykownym przedsięwzięciem, ponieważ rzuca wyzwanie, z jednej strony, silnie zestereotypizowanej wizji historii II wojny światowej, a z drugiej - wzorcom prozy postpamięciowej, wykształconym w docelowym systemie literackim. Rodzi się zatem podejrzenie, że taka proza jest narażona na ryzyko zmarginalizowania i ma niewielkie szanse na zaistnienie w kulturze przyjmującej. Tym samym obca Hiszpanom pamięć najprawdopodobniej nie zakotwiczy się, nie zostanie zasymilowana i, w zetknięciu z innym kontekstem odbioru, nie nabierze nowych, być może nieoczekiwanych znaczeń. Takie wnioski trzeba jednak formułować bardzo ostrożnie, wymagają one bowiem potwierdzenia dalszymi badaniami empirycznymi. Kolejnym krokiem w stronę ich zweryfikowania winna być analiza różnych aspektów recepcji przywołanych tu powieści, np. na podstawie recenzji publikowanych w prasie i Internecie, blogów i forów literackich oraz poświęconych II wojnie światowej.

\section{BIBLIOGRAFÍA}

Antologia de la poesía polaca, wybór F.P. Gonzáles, Barcelona 2006.

Bojarska K., Historia Zagtady i literatura niepiękna. „Tworki” Marka Bieńczyka w kontekście kultury posttraumatycznej, ,Pamiętnik Literacki” 2008, R. 48, nr 2.

Bond L., Rapson J., Introduction, [w:] The Transcultural Turn. Interrogating Memory Between and Beyond Borders, red. J. Rapson, L. Bond, Berlin 2004.

Bourdieu P., Les conditions sociales de la circulation international des idées, „Actes de la recherche en science sociales" 2002, nr 5, [online] https://doi.org/10.3917/arss.145.0003.

Crownshaw R., The Afterlife of Holocaust Memory in Contemporary Literature and Culture, Basingstoke 2010, Palgrave Macmillan Memory Studies.

Cuber M., Metonimie Zagtady. O polskiej prozie lat 1987-2012, Katowice 2013, Prace Naukowe Uniwersytetu Ślaskiego w Katowicach, nr 3027.

Cuñado I., Despertar tras la amnesia. Guerra civil y postmemoria en la novela española del siglo XXI, „Dissidences. Hispanic Journal of Theory and Criticism” 2012, Vol. 2, nr 3, [online] http://digitalcommons.bowdoin.edu/dissidences/vol2/iss3/8. 
Earl A., Rigney A., Travelling Memory, „Parallax” 2011, Vol. 17, nr 4, [online] https://doi.org/ 10.1080/13534645.2011.605570.

Empire, Colony, Genocide. Conquest, Occupation, and Subaltern Resistance in World History, red. A.D. Moses, New York-Oxford 2010.

Encyklopedia jezzykoznawstwa ogólnego, red. K. Polański, Wrocław 1995.

Even-Zohar I., Miejsce literatury ttumaczonej w polisystemie literackim, przeł. M. Heydel, [w:] Wspótczesne teorie przektadu. Antologia, red. P. Bukowski, M. Heydel, Kraków 2009.

Hirsch M., Family Pictures. Maus, Mourning and Post-Memory, „Discourse” 1992-1993, Vol. 15, nr 2.

Hirsch M., The Generation of Postmemory, „Poetics Today” 2008, Vol. 29, nr 1, [online] https:// doi.org/10.1215/03335372-2007-019.

Karolak C., Problemy odbioru tekstu literackiego w warunkach obcokulturowych, „Lingua ac Communitas" 1999, nr 9.

Lalewicz J., Semantyczne wyznaczniki lektury, [w:] Problemy odbioru i odbiorcy, red. T. Bujnicki, J. Sławiński, Wrocław 1977, Z Dziejów Form Artystycznych w Literaturze Polskiej, t. 47.

Liikanen E., Novelar para recordar. La posmemoria de la guerra civil y el franquismo en la novela española de la democracia. Cuatro casos, Congreso La Guerra Civil Española 1936-39, 2006, [online] http://www.secc.es/media/docs/33_4_LII_KANEN.pdf.

Mach A., Ktopotliwa (nie)pamięć o Zagtadzie. Wymazywanie żydowskości w recepcji i ekranizacji „Weisera Dawidka” Pawta Huellego, „Rocznik Komparatystyczny - Komparatistisches Jahrbuch" 2014.

Martínez R.J., La novela de investigación de escritor. Representaciones de la ambigüedad en la narrativa hispánica contemporánea (2001-2012), praca doktorska, [online] http://roderic.uv.es/ bitstream/handle/10550/32094/La\%20Novela\%20de\%20Investigaci\%C3\%B3n\%20 de\%20Escritor.pdf ? sequence $=1$.

Narębska I., Literatura polaca en España (1939-1975). Autores, editores, traductores, Wrocław 2015, Biblioteka Iberoromańska, t. 1.

Orwid M., Przeżyć... i co dalej?, rozmawiają K. Zimmerer, K. Szwajca, Kraków 2006.

Orwid M., Trauma, Kraków 2009.

Paleczny T., Transgresja jako nastepstwo kontaktu kulturowego, [w:] Transgresja w kulturze, red. T. Paleczny, J. Talewicz-Kwiatkowska, Kraków 2014, Varia Culturalia.

Pamięć trzeba otworzyć, z profesor Marią Orwid rozmawia Ewa Koźmińska-Frejlak, „Midrasz” 2005, Vol. 7-8.

Poesía a contragolpe. Antología de la poesía polaca contemporánea, wybór i przeł. A. Murcia, G. Beltrán, X. Farré, Zaragoza 2013.

Potok M., Estrategias literarias para la recuperación de la memoria histórica. La narrativa actual frente a la guerra civil, „Études romanes de Brno” 2012, Vol. 33, nr 2.

Rodríguez R.J., Literatura española de tema alemán (siglo XX), [online] http://cvc.cervantes.es/ literatura/aih/pdf/09/aih_09_2_039.pdf.

Sarlo B., Tiempo Pasado. Cultura de la memoria y giro subjetivo. Una discusión, Buenos Aires 2005.

Szwajca K., Pokolenie, które uczy się mówić, „Midrasz” 2005, Vol. 7/8. 
Szwajca K., Problemy tożsamości u dzieci ofiar Holocaustu, [online] http://dzieciholocaustu.org. $\mathrm{pl} /$ szab3.php?s=ostatni_szwajca.php.

Tokarz B., Tabu i autocenzura w przektadzie, [w:] Tabu w przektadzie, red. P. Fast, N. Strzelecka, Katowice 2007, Studia o Przektadzie, nr 23.

Ubertowska A., Świadectwo, trauma, gtos. Literackie reprezentacje Holokaustu, Kraków 2007, Modernizm w Polsce, t. 16.

Weissman G., Fantasies of Witnessing. Writing and Visual Culture after the Holocaust, New York 2004.

Wyszyńska J., Situación de la literatura polaca sobre la Segunda Guerra Mundial en España, [w:] Ideologias en traducción. Literatura, didáctica, cultura, red. I. Kasperska, L.I. Villegas, A.D. Mendia, Frankfurt am Main 2016.

Zaboklicka B., Literatura polska w Hiszpanii. Obecna, choć nieznana, [w:] Polonistyka bez granic, t. 1: Wiedza o literaturze i kulturze, red. R. Nycz, W. Miodunka, T. Kunz, Kraków 2010.

Dr hab. Małgorzata GASZYŃSKA-MAGIERA, prof. UW - iberystka. Pracuje w Instytucie Lingwistyki Stosowanej Uniwersytetu Warszawskiego. Zajmuje się teorią przekładu literackiego, lingwistyką kulturową oraz metodyką nauczania języka polskiego jako obcego. Na jej dorobek składają się dwa podręczniki do nauczania języka polskiego jako obcego, monografie Granice przektadalności. Subjuntivo i jego polskie ekwiwalenty w ttumaczeniach prozy iberoamerykańskiej (1997) i Recepcja przektadów literatury iberoamerykańskiej $w$ Polsce $w$ latach 1945-2005 z perspektywy komunikacji międzykulturowej (2011) oraz artykuły poświęcone glottodydaktyce, translatoryce oraz recepcji literackiej. Była współredaktorem numeru „Politei” (nr 35) poświęconego problematyce postpamięciowej. Inicjatorka cyklu konferencji pt. „Oblicza postpamięci”. 